\title{
ВПЛИВ СТЕНОЗУ АОРТОКЛУБОВОГО СЕГМЕНТА НА УЛЬТРАСТРУКТУРНУ ОРГАНІЗАЦЮЮ ГЕМОКАПІЛЯРІВ ГОЛОВНОГО МОЗКУ В ЩУРІВ
}

\begin{abstract}
Резюме. Зміна характеру центральної гемодинаміки може як передувати, так і ускладнювати перебіг гострого ішемічного ураження головного мозку. Причому серцево-судинні порушення, що призводять до розвитку гострого ішемічного ураження головного мозку, складають близько 30-40 \% у структурі усіх патогенетичних варіантів.

Мета дослідження - встановити особливості ультраструктурних змін у стінках гемокапілярів головного мозку щурів після стенозу аортоклубового сегмента.

Матеріали і методи. Експерименти проведено на 18 статевозрілих білих лабораторних щурах-самцях масою тіла 160-180 г. 3 них 3 тварини склали контрольну групу. Іншим 15 щурам під кетаміновим знеболюванням звужували черевний відділ аорти безпосередньо над її біфруркацією на 2/3 діаметра. Матеріал для електронно-мікроскопічних досліджень забирали через 1; 3; 7; 14 і 28 діб після операції згідно із загальноприйнятою методикою.

Результати досліджень та їх обговорення. Проведене електронно-мікроскопічне дослідження структурних компонентів кори півкуль головного мозку щурів після експериментального стенозу каудального відділу черевної аорти свідчить про етапність морфофункціональної перебудови та ремоделювання гемомікроциркуляторної ланки, у динаміці яких можна виділити наступні періоди:

- альтерації (набряк цитоплазми ендотеліоцитів з одночасними деструктивними змінами органел, нерівномірним потовщенням базальної мембрани та розширенням периваскулярних просторів) - безпосередньо після стенозування і до 3-ї доби спостереження; - адаптаційно-компенсаторних змін - з 3-ї до 7-ї доби експерименту зі стабілізацією морфофункціонального стану гемомікроциркуляторного русла (зменшення набряку цитоплазми ендотеліоцитів, більш збережений стан органел, чіткі контури базальної мембрани); - відновні - 3 14-ї до 28-ї доби спостереження із зворотним розвитком альтераційних змін і суттєвим, однак не повним, відновленням початкового стану структурних компонентів стінок гемокапілярів головного мозку.

Висновки. Морфофункціональна перебудова та ремоделювання структурних компонентів гемокапілярів кори півкуль головного мозку щурів після експериментального стенозу каудального відділу черевної аорти відбуваються поступово за наступними періодами: альтерації - безпосередньо після стенозування і до 3-ї доби спостереження; компенсації - з 3-ї до 7-ї доби експерименту і часткового відновлення у більш віддалені терміни.
\end{abstract}

Ключові слова: гемокапіляри; набряк; деструкція; органели; ендотеліоцити.

ВСТУП Проблема судинних захворювань головного мозку, пов'язаних із розладами його кровопостачання, $€$ однією з важливих проблем медицини протягом останніх десятиліть [1-3], що зумовлено їх високою часткою в структурі захворюваності й смертності населення, а також значними показниками тимчасових трудових втрат і первинної інвалідності [4-7].

Крім того, встановлено, що зміна характеру центральної гемодинаміки може як передувати, так і ускладнювати перебіг гострого ішемічного ураження головного мозку. Причому серцево-судинні порушення, що призводять до розвитку гострого ішемічного ураження головного мозку, складають близько 30-40 \% у структурі усіх патогенетичних варіантів перебігу розладів мозкового кровообігу [8].

Для розуміння патогенезу захворювань, в основі яких лежить гіпоксія мозку, винятково великого значення набувають експериментальні морфологічні дослідження, спрямовані на вивчення нормальної архітектоніки кори півкуль великого мозку, а також встановлення характеру змін у ній при різноманітних патологічних станах та в період відновлення фрункцій, особливо за умови їх інтенсифрікації шляхом хірургічного, медикаментозного чи будь-якого іншого впливу [3, 9, 10]. Результати таких досліджень можуть сприяти покращенню методів діагностики та вибору оптимальних методів лікування хворих із розладами мозкового кровообігу.

Метою дослідження було встановити особливості ультраструктурних змін у стінках гемокапілярів головного мозку щурів після стенозу аортоклубового сегмента.

МАТЕРІАЛИ I МЕТОДИ Експерименти проведено на 18 статевозрілих білих лабораторних щурах-самцях масою тіла 160-180 г. 3 них 3 тварини склали контрольну групу. Іншим 15 щурам під кетаміновим знеболюванням звужували черевний відділ аорти безпосередньо над її бісуркацією на 2/3 діаметра за оригінальним способом [11]. Матеріал для електронно-мікроскопічних досліджень забирали через 1; 3; 7; 14 і 28 діб після операції згідно із загальноприйнятою методикою. Ультратонкі зрізи, виготовлені на ультрамікротомі LKB-3 (Швеція), контрастували 1 \% водним розчином уранілацетату та цитратом свинцю згідно з методом Рейнольдса і вивчали в електронному мікроскопі ПЕМ-125К.

Усі експериментальні дослідження виконували відповідно до принципів біоетики, що викладені у Гельсинській декларації та Законі України “Про захист тварин від жорстокого поводження" (№ 1759-VI від 15.12.2009), що підтверджено комісією з біоетики дВНЗ "Тернопільський державний медичний університет імені І. Я. Горбачевського МОЗ України" (протокол № 34 від 01.03.2016).

РЕЗУЛЬТАТИ ДОСЛІДЖЕНЬ ТА ЇХ ОБГОВОРЕННЯ Субмікроскопічно на 1-шу добу експерименту в корі головного мозку щурів після оклюзії аортоклубового сегмента з боку гемомікроциркуляторного русла спостерігали зміни реактивного характеру. Вони проявлялися набряком цитоплазми ендотеліоцитів з одночасними деструктивними змінами органел, нерівномірним потовщенням базальної мембрани та розширенням периваскулярних просторів (рис. 1). Просвіт таких мікросудин був також розширеним і нерідко заповненим еритроцитами.

На цьому тлі у пірамідальних нейроцитах виявляли зміни, які полягали у посиленні інвагінацій каріолеми, локальних порушеннях чіткості структурної організації ядерних мембран. У каріоплазмі переважав еухроматин нерідко з білякаріолемною конденсацією. Спостерігали нерівномірне розширення і фррагментацію канальців ендоплазматичної сітки, зменшення на їі мембранах кількості рибосом з одночасним збільшенням розмірів цис- 


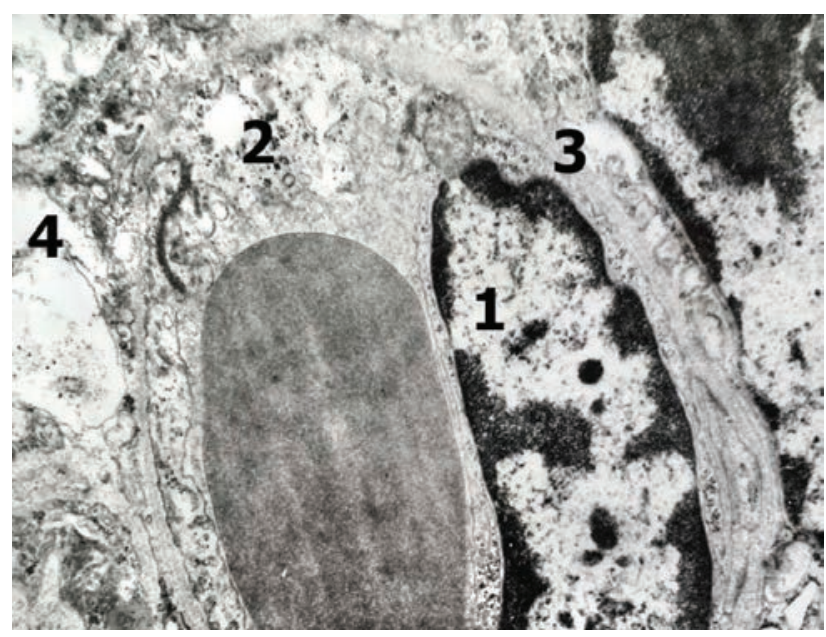

Рис. 1. Електронно-мікроскопічні зміни гемокапіляра кори головного мозку щура через 1 добу після експериментального стенозу каудального відділу черевної аорти. х 9000: 1 - ядро ендотеліоцита, 2 - набрякла ділянка цитоплазми ендотеліоцита, 3 - базальна мембрана; 4 - розширений периваскулярний простір.

терн комплексу Гольджі. Наростала кількість мітохондрій. Для більшості з них була характерною гіпертрофрія з одночасним просвітлення матриксу та деструкцією крист.

При проведенні електронно-мікроскопічного дослідження на 3-ю добу експерименту було встановлено подальше наростання змін, виявлених попередньо, що призводили до ушкодження ендотеліоцитів стінок гемокапілярів. Їх ядра набували неправильної форми унаслідок утворення і посилення інвагінацій каріолеми в електронну щільну каріоплазму. В цитоплазмі таких клітин була деструкція органел та формування вакуолей. Базальна мембрана на значних ділянках ставала розпушеною, нечітко контурованою, помітно розширювалися периваскулярні простори (рис. 2).

На даний термін експерименту в корі головного мозку тварин поряд із "темними" гіперхромними нейроцитами досить часто виявлялися "світлі" гіпохромні нейроцити із просвітленням матриксів каріо- й гіалоплазми.

Починаючи з 7-ї і до 14-ї доби експерименту, спостерігали ознаки розвитку відновних процесів у гемомікроциркуляторному руслі головного мозку тварин. У частині гемокапілярів ще зберігалося розширення просвітів 3 наявністю у них еритроцитів, однак набряк цитоплазми ендотеліоцитів був значно менше виражений, ніж у попередні терміни спостереження. У більш збереженому стані перебували органели. Периваскулярні простори місцями також ще залишалися дещо розширеними, однак базальна мембрана була вже чітко контурованою (рис. 3).

Для нейроцитів кори головного мозку на 7-му і 14-ту доби експерименту також було характерним покращення їх ультраструктурної організації.

Спостереження у 28-денний термін дозволило встановити подальшу нормалізацію гемомікроциркуляції. Однак повного відновлення структурної організації досліджуваних компонентів не відбувалося, про що свідчили залишкові явища від попередніх змін. Зокрема, для більшості гемокапілярів ще залишалися характерними помірно розширені просвіти, просвітлені цитоплазматичні ділянки ендотеліальних клітин. Базальна мембрана була чітко контурована, периваскулярні простори лише місцями були незначно розширеними (рис. 4).

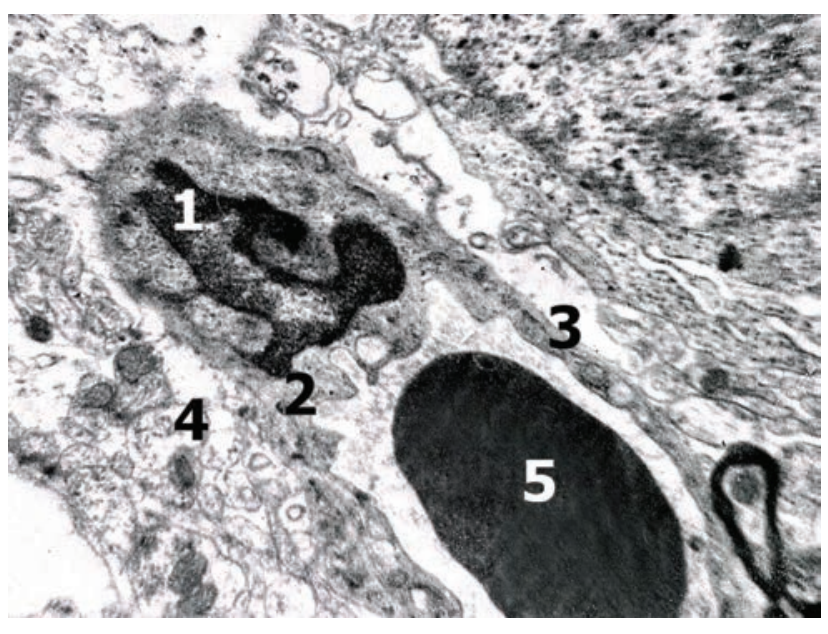

Рис. 2. Ультраструктурні зміни гемокапіляра кори головного мозку тварини через 3 доби після експериментального стенозу каудального відділу черевної аорти. х 9000: 1 - ядро ендотеліоцита; 2 - цитоплазма ендотеліоцита; 3 - базальна мембрана; 4 - розширений периваскулярний простір; 5 - еритроцит.

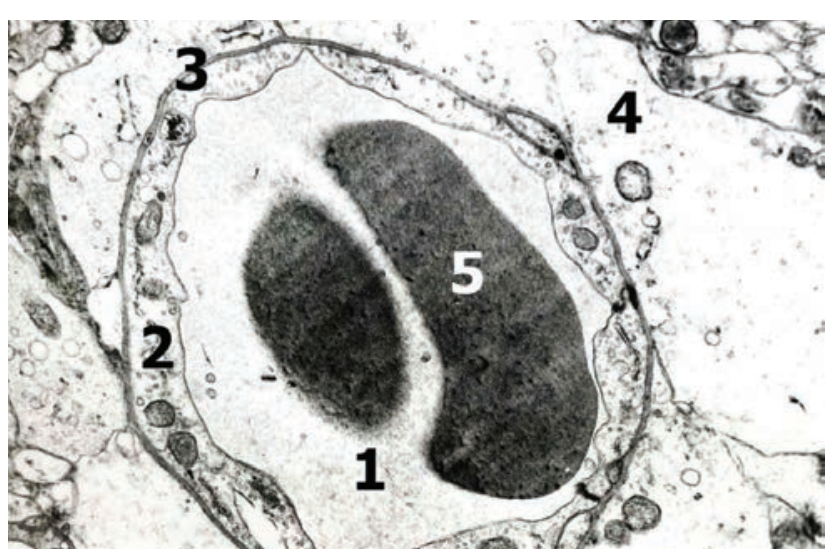

Рис. 3. Ультраструктурні зміни гемокапіляра кори головного мозку тварини через 7 діб після експериментального стенозу каудального відділу черевної аорти. х 9000: 1 - просвіт гемокапіляра; 2 - цитоплазма ендотеліоцита; 3 - базальна мембрана; 4 - розширений периваскулярний простір; 5 - еритроцити у просвіті мікросудини.

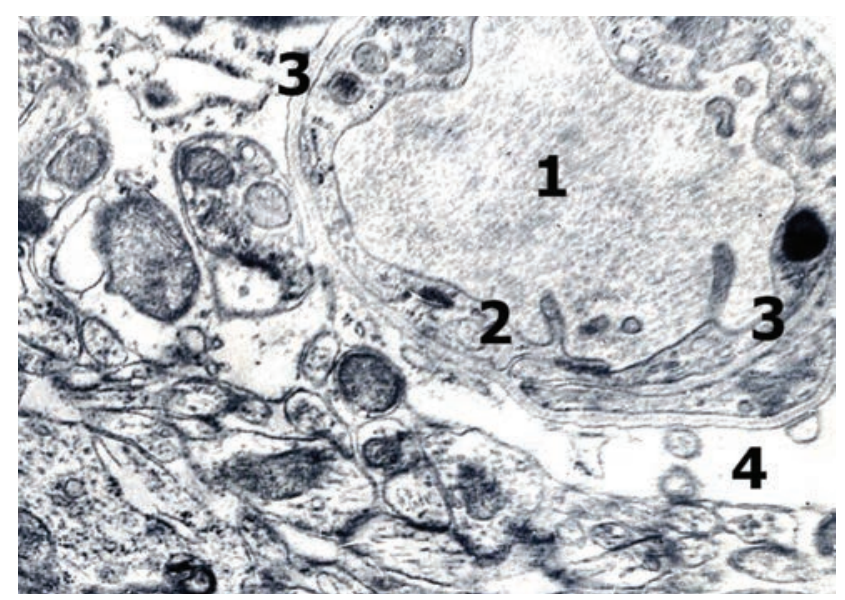

Рис. 4. Ультраструктурні зміни гемокапіляра кори головного мозку щура через 28 діб після експериментального стенозу каудального відділу черевної аорти. х 9000: 1 - просвіт гемокапіляра; 2 - цитоплазма ендотеліоцита; 3 - базальна мембрана; 4 - периваскулярний простір. 
На даний період спостереження у корі півкуль головного мозку щурів спостерігали значне збільшення питомої частки нормохромних нейроцитів.

Таким чином, провендене електронно-мікроскопічне дослідження структурних компонентів кори півкуль головного мозку щурів після експериментального стенозу каудального відділу черевної аорти свідчить про етапність морфоорункціональної перебудови та ремоделювання гемомікроциркуляторної ланки, у динаміці яких можна виділити наступні періоди:

- альтерації - безпосередньо після стенозування і до 3-ї доби спостереження;

- адаптаційно-компенсаторні зміни - з 3-ї до 7-ї доби експерименту зі стабілізацією морфоорункціонального стану гемомікроциркуляторного русла і цитоархітектоніки кори головного мозку;
- відновні - $з$ 14-ї до 28-ї доби спостереження із зворотним розвитком альтераційних змін і суттєвим, однак не повним, відновленням вихідного стану структурних компонентів гемокапілярів і нейроцитів головного мозку.

ВИСНОВКИ Морфофрункціональна перебудова та ремоделювання структурних компонентів гемокапілярів кори півкуль головного мозку щурів після експериментального стенозу каудального відділу черевної аорти відбуваються поступово за наступними періодами: альтерації - безпосередньо після стенозування і до 3-ї доби спостереження; компенсації - 3 3-ї до 7-ї доби експерименту і часткового відновлення у більш віддалені терміни.

Перспективи подальших досліджень Подальші дослідження дозволять обґрунтувати ефективність реперфузії головного мозку після декомпресії аортоклубового сегмента.
СПИСОК ЛІТЕРАТУРИ

1. Гусев Е. И. Ишемия головного мозга / Е. И. Гусев, В. И. Скворцова. - М. : Медицина, 2001. - 328 с.

2. Нарушения мозгового кровообращения, комбинированная терапия дисциркуляторной энцефалопатии / П. Р. Камчатнов, А. В. Чугунок, С. А. Воловец, Х. Я. Умарова // Мистецтво лікування. - 2007. - № 7 (633). - С. 32-36.

3. Приходько В. Ю. Хроническая ишемия мозга в практике врача-терапевта / В. Ю. Приходько // Здоров'я України. - 2007. - № 6 (163). - С. 15.

4. Беленичев И. Ф. Современные подходы к терапии острого нарушения мозгового кровообращения. Стратегии нейропротекции / И. Ф. Беленичев, М. П. Бухтиярова, Д. А. Середа // Новости медицины и срармации. - 2008. - № 5 (237). - С. 4-21.

5. Малая Л. Т. Эндотелиальная диссункция при патологии сердечно-сосудистой системы / Л. Т. Малая, А. Н. Корж, Л. Б. Балковая. - Харьков : ТОРСИНГ, 2000. - 315 с.

6. Особенности функционального состояния эндотелия сосудов у новорожденных с постгипоксическими нарушениями сердечно-сосудистой системы / Н. В. Харламова, Т. В. Чаша, Г. Н. Кузьменко, И. Г. Попова // Детские болезни сердца и сосудов. - 2009. - № 3. - С. 64-69.
7. The pivotal role of endotelium in hypertension / S. Taddei, A. Virdis, L. Chiadoni, A. Salvetti // Medicographia. - 1999. - Vol. 21 (1), Issue 59. - P. 22-29.

8. Виленский Б. С. Инсульт: профилактика, диагностика и лечение / Б. С. Виленский. - М., 2002. - 397 с.

9. Нейроно-глиально-капиллярные взаимоотношения в различных структурах головного мозга человека / С. Ю. Масловский, А. Ю. Степаненко, Н. Е. Пирятинская // Вісник морфології. - 2010. - Т. 16, № 1. - С. 85-88.

10. Рыженкова И. В. Возрастные особенности нейроноглиально-капиллярных взаимоотношений в предцентральной извилине головного мозга человека / И. В. Рыженкова, С. Ю. Масловский // Медицина сьогодні і завтра. - 2009. - № 1. - C. $39-41$.

11. Пат. 60262 Україна, МПК А 61 М 5/00, G 09 В 23/00. Пристрій для дозованого звуження судин / Герасимюк I. Є., Пилипко І. В., Островська Л. О.; заявник і власник патента Тернопільський державний медичний університет імені І. Я. Горбачевського. № u201015339 ; завл. 20.12.2010 ; опубл. 10.06.2011, Бюл. № 11.

Отримано 02.10.18

Електронна адреса для листування: herasymyuk@tdmu.edu.ua

\section{THE INFLUENCE OF STENOSIS OF AORTOILIAC SEGMENT ON ULTRASTRUCTURAL ORGANIZATION OF HEMOCAPILLARIES} OF THE MAIN BRAIN IN RATS

Summary. Changing the nature of central hemodynamics can both precede and complicate the course of acute ischemic lesion of the brain. Moreover, cardiovascular disorders, leading to the development of acute ischemic lesion of the brain, make up about 30-40 \% in the structure of all pathogenetic variants.

The aim of the study - to determine the peculiarities of ultrastructural changes in the capillaries walls of rats brain after aortoiliac segment stenosis.

Materials and Methods. Experiments were carried out on 18 sexually mature white laboratory male rats weighing $160-180 \mathrm{~g}$. Among them 3 animals were in the control group. The other 15 rats were under ketamine anesthesia constricted the aorta stenosis directly over its bifurcation by $2 / 3$ of a diameter. The material for electron microscopic studies was taken after $1,3,7,14$ and 28 days after surgery in accordance with the generally accepted method.

Results and Discussion. The conducted electron microscopic study of structural components of the cerebral cortex of the rats brain after the experimental stenosis of the caudal part of the abdominal aorta leads to the stage of morphofunctional and remodeling changes of the microcirculatory flow in the dynamics of which the following periods can be distinguished:

- alterations (edema of the endothelial cell cytoplasm with simultaneous destructive organelle changes, uneven thickening of the basal membrane and perivascular spaces extension) - immediately after stenosis and before the 3rd day of observation; 
- adaptive-compensatory changes - from the 3rd to the 7th day of the experiment with the stabilization of the morphofunctional state of the microcirculatory flow (reduction of edema of the endothelial cell cytoplasm, more stable organelles state, clear contours of the basal membrane);

- restorations - from the 14th to the 28th day of observation with the backward development of alterational changes and significant, but not complete, restoration of the initial state of structural components of the brain hemocapillary walls.

Conclusions. Morphofunctional remodeling of the rats cerebral cortex structural components after the experimental stenosis of the caudal part of the abdominal aorta caused changes according the following periods: alterations - immediately after stenosis and before the 3rd day of observation; compensation - from the 3rd to the 7th day of the experiment and partial restoration in more distant terms.

Key words: capillaries; edema; destruction; organelles; endothelial cells.

○Ю. Н. Гаврищук, И. Е. Герасимюк, Т. Р. Геник

ГВУз “Тернопольский государственный медицинский университет имени И. Я. Горбачевского”

\section{ВЛИЯНИЕ СТЕНОЗА АОРТОПОДВЗДОШНОГО СЕГМЕНТА НА УЛЬТРАСТРУКТУРНУЮ ОРГАНИЗАЦИЮ ГЕМОКАПИЛЛЯРОВ} МОЗГА У КРЫС

Резюме. Изменение характера центральной гемодинамики может как предшествовать, так и осложнять течение острого ишемического поражения головного мозга. Причем сердечно-сосудистые сдвиги, приводящие к развитию острого ишемического поражения головного мозга, составляют около 30-40 \% в структуре всех патогенетических вариантов.

Цель исследования - установить особенности ультраструктурных изменений в стенках гемокапилляров головного мозга крыс после стеноза аортоподвздошного сегмента.

Материалы и методы. Эксперименты проведены на 18 половозрелых белых лабораторных крысах-самцах массой тела 160-180 г. Из них 3 животных составили контрольную группу. Другим 15 крысам под кетаминовым обезболиванием осуществляли сужение брюшного отдела аорты непосредственно над ее бифруркацией на 2/3 диаметра. Материал для электронномикроскопических исследований забирали через 1; 3; 7; 14 и 28 суток после операции по общепринятой методике.

Результаты исследования и их обсуждение. Проведенное электронно-микроскопическое исследование структурных компонентов коры полушарий головного мозга крыс после экспериментального стеноза каудального отдела брюшной аорты свидетельствует об этапности морфоорункциональной перестройки и ремоделирования гемомикроциркуляторного звена, в динамике которых можно выделить следующие периоды:

- альтерации (отек цитоплазмы эндотелиоцитов с одновременными деструктивными изменениями органелл, неравномерным утолщением базальной мембраны и расширением периваскулярных пространств) - непосредственно после стенозирования и до 3-х суток наблюдения;

- адаптационно-компенсаторных изменений - с 3-х по 7-е сутки эксперимента со стабилизацией морсрофункционального состояния гемомикроциркуляторного русла (уменьшение отека цитоплазмы эндотелиоцитов, более сохранное состояние органелл, четкие контуры базальной мембраны);

- восстановления - с 14 по 28-е сутки наблюдения с обратным развитием альтерационных изменений и существенным, однако не полным восстановлением исходного состояния структурных компонентов стенок гемокапилляров головного мозга. Выводы. Морфосункциональная перестройка и ремоделирование структурных компонентов гемокапилляров коры полушарий головного мозга крыс после экспериментального стеноза каудального отдела брюшной аорты происходят последовательно по следующим периодам: альтерации - непосредственно после стенозирования и до 3-х суток наблюдения; компенсации - с 3-х по 7-е сутки эксперимента и частичного восстановления в более отдаленные сроки.

Ключевые слова: гемокапилляры; отек; деструкция; органеллы; эндотелиоциты. 